\title{
THE WELFARE-NIHILIST ARGUMENTS AGAINST JUDGMENT SUBJECTIVISM
}

\author{
Anthony Kelley
}

$(1)$

NE WAY to construe subjectivism about well-being is as the view that $x$ is basically good for $S$ if and only if, because, and to the extent that $x$ is valued, under the proper conditions, by $S .{ }^{1}$ Dale Dorsey argues for an idealized, judgment-based theory of valuing, one according to which a person values a thing if and only if, because, and to the extent that she would believe, under the proper conditions, that it is basically good for herself. ${ }^{2}$ Call subjectivism about well-being coupled with a judgment-based theory of valuing judgment subjectivism. ${ }^{3}$

Judgment subjectivism is a remarkable theory, and Dorsey's case for it is compelling. If the theory is true, then what is good for you is wholly determined by what you believe is good for you. It is somewhat surprising that it has not been the subject of much scrutiny. ${ }^{4}$ In this paper, I offer three related arguments against the theory. The arguments are about what judgment subjectivism implies about the well-being of welfare nihilists, people who believe that there are no welfare properties or at least that none are instantiated. I maintain that wel-

1 This construal is Dale Dorsey's; see Dorsey, “Subjectivism without Desire," 407. One controversial feature of Dorsey's statement of subjectivism is that it requires that a theory link a person's good to her values in order for it to count as subjectivist. It is more common in the well-being literature to deem as subjectivist any theory that links a person's good to her pro-attitudes more generally (and not only to the pro-attitudes that constitute her values). See, for example, Heathwood, "Subjective Theories of Well-Being," 205; Lin, "Against Welfare Subjectivism," 354; and Sumner, Welfare, Happiness and Ethics, 38.

2 See Dorsey, "Subjectivism without Desire," "Idealization and the Heart of Subjectivism," and "Why Should Welfare 'Fit'?"

3 Each theory-subjectivism, a judgment-based theory of valuing, and judgment subjectivism-includes "because," "to the extent that," and "under the proper conditions" clauses. To make the discussion less onerous, I will mostly drop these clauses when discussing these theories. Also, in what follows, all references to welfare value or to what is good (bad) for a person are references to what is basically good (bad) for a person (i.e., good (bad) for the person non-derivatively and as an end).

4 An important exception is Lin, "Against Welfare Subjectivism." 
fare nihilists can be benefited and harmed. Judgment subjectivism is implausible because it implies otherwise.

In section 1, I explain judgment subjectivism, and in section 2, I present the welfare-nihilist arguments against the theory. In section 3, I explain how my objection to the theory is better, in at least one important respect, than a similar objection in the well-being literature. In section 4, I respond to some objections.

\section{JUDGMENT SUBJECTIVISM}

The central motivation for judgment subjectivism is the alienation constraint, the doctrine that a person cannot be alienated from that which is basically good for her. Sometimes referred to as "internalism about prudential value" or the "resonance constraint," it is commonly understood as the requirement that in order for something to be good for a person, she must have a pro-attitude toward it. ${ }^{5}$ A person's pro-attitudes are her noncognitive attitudes like being pleased, desiring, enjoying, and liking or her evaluative cognitive attitudes like believing that something is of value. ${ }^{6}$ The alienation constraint is motivated by cases where it seems at least plausible to say that something is not good for a person because the person is not at all interested in it.

From this starting point, Dorsey arrives at judgment subjectivism in two steps. The first step is to argue that, in order to accommodate our intuitions about how a person's good cannot be alien to her-that is, in order to accommodate the alienation constraint-theories of well-being must tie a person's good to the pro-attitudes that constitute her values and not just to any pro-attitude or other. Dorsey claims that a theory that ties a person's good to some pro-attitude that is not a valuing attitude risks alienating a person from her good. ${ }^{7}$ The argument for this claim appeals to the case of a recovering addict who desires,

5 In a canonical expression of the resonance constraint, Railton writes: "It does seem to me to capture an important feature of the concept of intrinsic value to say that what is intrinsically valuable for a person must have a connection with what he would find in some degree compelling or attractive, at least if he were rational and aware. It would be an intolerably alienated conception of someone's good to imagine that it might fail in any such way to engage him" ("Facts and Values," 9). For arguments in favor of the resonance constraint, see Rosati, "Internalism and the Good for a Person"; Dorsey, "Why Should Welfare 'Fit'?" For criticisms of Rosati's arguments, see Dorsey, "Why Should Welfare 'Fit'?"; Sarch, "Internalism about a Person's Good." Sarch also discusses an argument against Rosati's preferred formulation of the constraint ("Internalism about a Person's Good").

6 For the purposes of this paper, I will follow Dorsey in characterizing evaluative beliefs as pro-attitudes ("Subjectivism without Desire").

7 A valuing attitude is an attitude such that if a person takes up that attitude toward an object, then she values it. 
but does not value, taking an addictive drug. It would be to adopt an intolerably alienating conception of her good, Dorsey claims, to say that taking the addictive drug is good for her when doing so conflicts with her values. ${ }^{8}$

The second step is to give a theory of valuing. ${ }^{9}$ A judgment-based theory of valuing identifies valuing with belief or judgment (I will use the two interchangeably). The theory says that $S$ values $x$ if and only if $S$ believes, under the proper conditions, that $x$ is good for $S$. There are some troubling cases for the theory. I will mention two here.

Suppose that some of my beliefs about what is good for me are in tension with some of my other beliefs about what is good for me. For example, suppose that I believe that being a philosopher is good for me, but I do not believe that the activities that are constitutive of being a philosopher are good for me. Plausibly, if one does not value the activities constitutive of being a philosopher, one does not value being a philosopher. Thus, the judgment-based theory of valuing seems to imply, implausibly, that I both value and do not value being a philosopher. $^{10}$

Another problem case is this: suppose that I believe that being a philosopher is good for me, but I have a mistaken view of what being a philosopher is like. Suppose further that if I knew what being a philosopher is really like, I would not believe that being a philosopher is good for me. Perhaps, for example, I believe that being a philosopher is good for me on the basis of the prospects of the fortune and fame I associate with being a philosopher, and that I would not believe that being a philosopher is good for me if it were not for this mistaken view of what being a philosopher is like. The judgment-based theory of valuing seems to imply, implausibly, that I value being a philosopher when I do not value what it is really like to be a philosopher (philosophy, perhaps regrettably, is not a reliable path to fortune and fame).

We can specify the theory in a way that avoids these objections. The theory says that $S$ 's beliefs determine, under the proper conditions, what $S$ values. Dorsey suggests that the proper conditions include a coherence condition. ${ }^{11}$ In the case where I believe that being a philosopher is good for me, and I also believe that

8 See Dorsey, "Idealization and the Heart of Subjectivism," 200-1.

9 More specifically, Dorsey takes himself to be giving a theory of prudential valuing. According to Dorsey, prudential valuing is the kind of valuing that is self-interested and thereby most plausibly related to well-being. For example, Dorsey distinguishes between the way that he might value a stranger's broken leg being healed and the way he values being a philosopher. He says that he values the former in a non-prudential way and that he values the latter in a different, prudential way. See Dorsey, "Subjectivism without Desire," 419-22. 
doing the activities that are constitutive of being a philosopher is not good for me, my beliefs about what is good for me are incoherent. Once my beliefs about what is good for me are rendered coherent, I will either believe both that being a philosopher and that the activities constitutive of being a philosopher are good for me or I will not believe that being a philosopher is good for me at all.

What of the case where I believe that being a philosopher is good for me but on the basis of a misunderstanding of what being a philosopher is like? To accommodate this kind of case, Dorsey specifies the theory's proper-conditions clause to include a condition of full consideration. ${ }^{12}$ Provided that I would not maintain my belief that being a philosopher is good for me if I had fully considered the relevant ways that being a philosopher is like, then the judgment-based theory of valuing that includes a condition of full consideration would not imply that I value being a philosopher.

With these details, we can now state Dorsey's preferred formulation of judgment subjectivism:

Dorsey-Style Judgment Subjectivism: $x$ is good for $S$ if and only if $S$ would believe, if $S$ 's beliefs about what is good for $S$ were rendered coherent and if $S$ had fully considered all the (relevant) ways that $x$ might be, that $x$ is good for $S$.

The core of judgment subjectivism is a commitment to subjectivism and a judgment-based theory of valuing. Dorsey-style judgment subjectivism is one way to specify the theory's proper-conditions clause in light of the two problem cases just discussed. Dorsey's formulation of the theory is an idealized theory. It does not give the person's actual beliefs evaluative authority. Instead, whether $x$ is good for $S$ is determined by the beliefs that $S$ would have if her beliefs were rendered coherent and if she had fully considered all the (relevant) ways that $x$ might be. Other judgment subjectivists may wish to avoid idealization. ${ }^{13}$ The

Dorsey, "Idealization and the Heart of Subjectivism," 209.

Dorsey distinguishes between two ways that idealization might be incorporated into subjectivism. On Dorsey's understanding of subjectivism, the subjectivist says that something is good for a person if and only if she values it. The first way that idealization could enter the subjectivist picture would be for the subjectivist to say that it is not the person's actual values that determine what is good for her; instead, it is the values that she would have if she were, say, fully informed and fully rational. Now suppose that the subjectivist does not choose to idealize in this way. There is still a second way that idealization could enter the picture: the subjectivist might say that what it is for a person to value something is for her to have certain pro-attitudes under certain idealized conditions. Dorsey chooses to idealize in the second but not the first way; on his view, it is a person's actual values that determine what is good for her, but her actual values are revealed through what she would believe is 
welfare-nihilist arguments against judgment subjectivism, however, apply not just to Dorsey's particular formulation of the theory; they apply to any plausible version of the theory.

\section{THE WELFARE-NIHILIST ARGUMENTS}

Welfare nihilism is the view that there are no welfare properties or at least that none are instantiated. Judgment subjectivism has some implausible implications about the welfare of welfare nihilists. I will discuss three: that welfare nihilists cannot be benefited, that welfare nihilists cannot be harmed, and that for any two welfare nihilists, $A$ and $B$, the segment of $A$ 's life after $A$ becomes a welfare nihilist is no better or worse for $A$ than the corresponding segment of $B$ 's life is for $B$, no matter what these life segments are like.

\subsection{The First Argument}

Suppose that Felicity is a senior philosophy professor. In graduate school, she took a seminar in the metaphysics of value. She became convinced by various arguments that nothing is good or bad for anyone. After becoming a welfare nihilist, Felicity nonetheless experienced numerous pleasures and the satisfaction of her most enduring desires. She married a lovely and kind person with whom she is exceptionally happy. She loves her children, and they love her. She has published widely in philosophy. She has developed her musical talent as an expert pianist. She donates money to the poor, and she has a wide range of hobbies in which she often finds occasion to indulge. She is well respected, and she has many genuine friendships. At the age of eighty-five, Felicity dies just as she had always hoped that she would: painlessly and surrounded by her loved ones.

It is plain that Felicity led a good life. Furthermore, it is not that the goodness of Felicity's life is wholly explained by what occurred in her life before she became a welfare nihilist. The goodness of Felicity's life is explained, at least in part, by states of affairs that obtained after she became a welfare nihilist. ${ }^{14}$ Note that we need not agree on which states of affairs are good for Felicity after she became a welfare nihilist, and we need not agree on exactly why they were of benefit to her. I take it that virtually everyone, irrespective of their preferred the-

good for herself under idealized conditions. See Dorsey, "Idealization and the Heart of Subjectivism."

14 For simplicity, I am writing as if states of affairs are the bearers of prudential value, but I want to remain neutral on this controversial issue. Everything I say here could be restated in terms of whichever metaphysical entity one thinks is the bearer of welfare value. 
ory of well-being, would agree that Felicity was benefited by at least something after she became a welfare nihilist.

Dorsey-style judgment subjectivism, however, cannot accommodate this fact. The theory implies that $x$ is good for $S$ only if $S$ would believe, if her beliefs were rendered coherent and if she had fully considered all the (relevant) ways that $x$ might be, that $x$ is good for $S$. Felicity's beliefs about what is good for herself are consistent because she does not believe that anything is good for herself. There is also no difficulty in imagining that the full-consideration condition has been met. We can imagine that Felicity remained steadfast in her welfare nihilism even after fully considering every possible state of affairs that might be of benefit to her. Thus, Dorsey-style judgment subjectivism implies, implausibly, that Felicity was not benefited after she became a welfare nihilist.

This first welfare-nihilist argument, like the other two to follow, are not just a problem for Dorsey-style judgment subjectivism. Dorsey's formulation of the theory is a result of his preferred way of specifying the theory's proper-conditions clause. I will argue in section 4 that Felicity would not believe that anything is good for herself after she became a welfare nihilist under any plausible specification of the theory's proper-conditions clause. My argument there relies on the claim that some natural and plausible ways the judgment subjectivist might try to specify the proper-conditions clause to avoid my objection are inadequate for that task. This fact suggests (but, of course, does not entail) that there is no plausible way at all for the judgment subjectivist to specify the proper-conditions clause in order to avoid my objection.

One initial objection to this first argument is that I have begged the question against the judgment subjectivist. Only someone who is not a judgment subjectivist, the objector claims, would grant that Felicity is benefited after she became a welfare nihilist. I suspect, however, that if the judgment subjectivist puts aside his philosophical commitments and reflects on the case as anyone else would, he would agree that Felicity is benefited after becoming a welfare nihilist. Furthermore, the judgment subjectivist should be concerned with accommodating commonsense intuitions about welfare and not just the idiosyncratic intuitions of judgment subjectivists.

Even if the judgment subjectivist digs in his heels and insists that Felicity is never benefited after becoming a welfare nihilist, I do not think that my argument begs the question (or if it does, it is not an illicit instance of begging the question). I doubt, for example, that anyone would seriously think that Gettier begs the question (or that his begging the question is illicit) against the justified-true-belief theory of knowledge just because he assumes as a premise something that someone who digs in his heels and insists that the theory is true would 
reject (e.g., that Smith does not know that the man who will get the job has ten coins in his pocket). ${ }^{15}$ The issue of when an argument begs the question (illicitly) is beyond the scope of this paper, but we can at least say this: an expansive view according to which the welfare-nihilist arguments should be rejected on this basis is one that would condemn as fallacious virtually every philosophical argument that attempts to make problems for a theory by identifying its implausible implications. ${ }^{16}$

\subsection{The Second Argument}

Judgment subjectivism is a theory of well-being. Theories of well-being are theories about what is good for a person as well as what is bad for a person. For example, the hedonist claims that pleasurable experiences benefit a person whereas painful experiences harm. Similarly, we would expect a full statement of judgment subjectivism to say something about what is bad for a person. Dorsey does not discuss this element of the theory, so we must fill in some of the details for ourselves. The most natural suggestion is for the judgment subjectivist to say that $x$ is bad for $S$ if and only if $S$ would believe, under the proper conditions, that $x$ is bad for $S$.

This additional feature of judgment subjectivism suggests a different but related argument against the theory. Suppose that Mallory is a prisoner at a top-secret government compound. She is tortured daily. She has numerous painful experiences and her life is full of the frustration of her most enduring desires. Before her imprisonment, Mallory took a seminar in the metaphysics of value in graduate school. She became convinced by various arguments that nothing is good or bad for anyone. Mallory had many friends that have since lost all respect and affection for her after learning of her imprisonment for suspected terrorist activity. Upon her capture, Mallory's lovely and kind partner-with whom she was previously exceptionally happy_-divorced her. Her children despise her, and she has no opportunity to pursue the various projects that are important to her. She has no hobbies and no genuine friendships. Mallory never again sees the light of day and dies at the hands of her captors.

It seems plain that Mallory is harmed after she became a welfare nihilist. After all, it is not as if a person could avoid the harm of being tortured simply by convincing themselves of welfare nihilism. Even if we cannot agree as to exactly what is bad for her after she became a welfare nihilist or exactly why it is bad for her, surely we can all agree, irrespective of our preferred theory of well-being, that Mallory was harmed after she became a welfare nihilist.

Gettier, "Is Justified True Belief Knowledge?"

I thank an anonymous referee for pressing me on this point. 
Dorsey-style judgment subjectivism cannot accommodate this fact. Mallory's beliefs about what is bad for herself are coherent because she does not believe that anything is bad for herself, and we can simply imagine that the full-consideration condition has been met as well. Furthermore, Mallory would not, under any plausible specification of the proper-conditions clause, believe that anything is bad for herself, so this second welfare-nihilist argument, like the others, is a problem for any version of the theory. ${ }^{17}$

\subsection{The Third Argument}

I want to highlight one additional implausible implication of judgment subjectivism. To put the argument roughly: when I reflect on Felicity's life after she became a welfare nihilist, I find myself thinking that this period of Felicity's life is going by far better for her than the corresponding period of Mallory's life is going for her. The problem for judgment subjectivism is that it seems unable to accommodate this intuitive thought. As I will explain, the theory implies that Felicity's life after she became a welfare nihilist is of equal welfare value for her as Mallory's life after she became a welfare nihilist is for her.

For the discussion that follows, it will be helpful to introduce some terminology for ease of reference. Let us call the period of Felicity's life after she became a welfare nihilist Felicitous and the corresponding period of Mallory's life Maladious. It seems clear to me that Felicitous is better for Felicity than Maladious is for Mallory. In fact, I have a strong intuition that Felicitous is significantly better for Felicity than Maladious is for Mallory. Perhaps you share this intuition. But the claim we need for the third welfare-nihilist argument is weaker; all we have to say is that Felicitous is at least somewhat better for Felicity than Maladious is for Mallory. Everyone, irrespective of their preferred theory of well-being, should accept this weaker claim. Imagine that you are Felicity in the moment immediately after she became a welfare nihilist. Now suppose that you could choose, only taking into account considerations of your own welfare, either Felicitous or Maladious as your future. Surely you should not be indifferent between these two options; Felicitous is preferable precisely because it is the future that would be better for you.

Judgment subjectivism cannot accommodate this simple fact. There are two different versions of judgment subjectivism that we have to consider, each correer-conditions clause, believe that anything is good for herself. I trust that the reader can take what I say there, make the appropriate changes, and reason in the same fashion to the conclusion that Mallory also would not, under any plausible specification of the proper-conditions clause, believe that anything is bad for herself. 
sponding to a difference with respect to what the theory might say about how we should evaluate the welfare value of one of $S$ 's life segments for $S$. The judgment subjectivist might say that a life segment is good for a person just in case she believes at some specified time and under the proper conditions that it is good for herself. On a different approach, the theory would imply that a life segment is good for a person just in case there is a favorable balance of welfare goods to welfare bads accrued during that period of time.

Consider the first approach. Put aside the proper-conditions clause for the moment, because the strategy I employ in section 4.2 can be used to establish that Felicity would not, under any plausible specification of the proper-conditions clause, believe that Felicitous is good for herself and that Mallory would not, under any plausible specification of the proper-conditions clause, believe that Maladious is good for herself. What is of interest to us now is the fact that a fully specified version of the theory on this first approach would have to say when exactly $S$ must believe (under whatever proper conditions the theory specifies) that one of $S$ 's life segments is good for $S$. The main options are to require that $S$ believe that the life segment is good for herself before the life segment occurs, during the life segment, or after the life segment ends (or some combination of these). Irrespective of the details, on this approach the theory implies that the welfare value of Felicitous for Felicity is o provided that we stipulate that Felicity does not, at any time whatsoever, believe that Felicitous is good for herself. Mutatis mutandis with respect to what this version of the theory implies about the welfare value of Maladious for Mallory. Thus, on this first approach, Felicitous is no better for Felicity than Maladious is for Mallory.

Now consider the second approach. On this version of the theory, a life segment is good for a person just in case there is a favorable balance of welfare goods to welfare bads accrued during that period of time. On this way of evaluating the welfare value of a life segment, a life segment could be good for a person even if she does not believe that it is good for herself. As long as the life segment contains the right balance of welfare goods over welfare bads, then the life segment is good for her. Of course, according to judgment subjectivism, whether a life segment contains items that are welfare goods for $S$ will depend on $S$ 's beliefs about whether those items are good for herself, but on the version of the theory currently under consideration, whether the life segment itself is good for $S$ does not depend on whether $S$ believes that it is good for $S$.

This version of the theory implies that the welfare value of Felicitous for Felicity is o because Felicity does not, and would not under any plausible specification of the proper-conditions clause, believe that anything is good for herself during that period of time. According to the theory, Felicitous contains no wel- 
fare goods at all for Felicity. Mutatis mutandis with respect to what this version of the theory implies about the welfare value of Maladious for Mallory. Thus, irrespective of whether we take the first or second approach in explaining the welfare value of one of $S$ 's life segments for $S$, the theory has the implausible implication that Felicitous is no better for Felicity than Maladious is for Mallory. ${ }^{18}$

These three implausible implications of the theory-that Felicity is not benefited after becoming a welfare nihilist, that Mallory is not harmed after becoming a welfare nihilist, and that Felicitous is no better for Felicity than Maladious is for Mallory-are devastating. Note that the leading theories of well-being do not have these problems. Hedonism, the desire theory, and objective-list theories can each account, for example, for the fact that Felicity was benefited after she became a welfare nihilist. The hedonist will appeal to the pleasure that Felicity experienced, the desire theorist will appeal to the satisfaction of her desires, and the objective-list theorist will appeal to the relevant objective welfare goods that Felicity had in her life (e.g., her friendships, the development of her talents, and her achievements).

I have been assuming that we should reject the theory because it has the implausible implications that I have indicated. But why should that be? Every extant theory of well-being has some implausible implications. Theory choice is a complicated matter; we need to carefully weigh the virtues and vices of a theory against each other before rejecting it. The worry is that since I have not assessed all of judgment subjectivism's virtues and vices, I am not entitled to say that the theory should be rejected on the basis of the welfare-nihilist arguments.

These are sensible remarks. We certainly should not commit the mistake of prematurely rejecting a theory on the basis of just three implausible implications. But I do not think that rejecting judgment subjectivism on the basis of the welfare-nihilist arguments is premature. The implausible implications that I attribute to judgment subjectivism are very implausible implications about basic issues that any theory of well-being should get right. Felicity leads a paradigmatically good life, and Mallory leads a paradigmatically bad one. If a theory cannot deliver the correct verdicts in these kinds of cases, then we should jettison that theory for one that can. Nearly every extant theory of well-being can account for our intuitive judgments about Felicity's and Mallory's welfare after they became

This third welfare-nihilist argument may be thought to enjoy a certain advantage over the previous two. The previous arguments depend on absolute welfare claims (e.g., that Felicity was benefited after she became a welfare nihilist), whereas this argument does not. Instead, it depends on a purely comparative welfare claim. So even if someone is skeptical about absolute welfare claims, they can still believe that this third argument is sound. 
welfare nihilists except for judgment subjectivism. That is an embarrassment for the theory.

\section{LIN'S OBJECTION}

Eden Lin has recently posed an interesting and formidable challenge to judgment subjectivism that is related to the welfare-nihilist arguments. ${ }^{19} \mathrm{His}$ objection is related because it identifies a class of individuals who do not have beliefs about what is good or bad for themselves but who can nonetheless be benefited and harmed. Whereas Lin's objection is about newborn babies, mine is about welfare nihilists. In this section, I will explain Lin's objection and Dorsey's reply. Then I will show that my objection is superior to Lin's in an important respect: whatever purchase Dorsey's reply has with respect to Lin's objection, a similar reply is a nonstarter as a reply to the welfare-nihilist arguments.

Lin argues against a theory he calls "Same World Judgment Subjectivism," which he describes as the view that " $x$ is basically good for you at $W$ if and only if at $W$, you believe that $x$ is basically good for you." ${ }^{20}$ Lin's challenge comes in two steps. First, note that newborn babies do not have any beliefs about what is good for themselves. As Lin points out, "they like some things and are averse to others, and perhaps they have beliefs. But they surely do not have beliefs to the effect that $x$ is good for them."21 Second, note that newborn babies can clearly be harmed and benefited. As Lin writes, the fact that "a newborn can have a positive level of welfare ... implies that some things can be basically good for it." Thus, the judgment subjectivist is apparently wrong that in order for something to benefit a subject, she must believe that it is good for herself.

A natural response would be to say that judgment subjectivism applies to normal human adults but that some other theory applies to newborn babies. However, Lin argues that "if the view is restricted in this way, we should reject it [because] if the view is true of normal adults even though it is false of newborns, then adult welfare diverges from neonatal welfare in a way that cannot plausibly

19 See Lin, "Against Welfare Subjectivism."

20 Lin, "Against Welfare Subjectivism," 357. We have seen that the judgment subjectivist need not accept this claim because he might instead prefer an idealized version of the theory. Lin has an objection against idealized versions of the theory too. See Lin, "Against Welfare Subjectivism," 365-68.

21 Lin, "Against Welfare Subjectivism," 357. Lin points out that even if this is not true of newborns at this world, it is certainly true of some newborns at some possible worlds. That the theory cannot accommodate our intuitions about the welfare of these merely possible beings is still a problem for the theory. 
be explained." 22 Lin asks us to consider a newborn baby who has a high level of welfare. Suppose that hedonism is the correct theory of neonatal welfare. Suppose further that the newborn baby matures over time and develops the capacity to believe that some things are good for herself but that she does not believe that anything is good for herself. Lin describes the problem as follows:

If Same World Judgment Subjectivism becomes true of her at this point, then her welfare drops to zero (or lower) at that time-even though she continues to have exactly the same balance of pleasure over pain in virtue of which she was previously high in welfare. This is implausible. If those favorable hedonic conditions were formerly sufficient for a high level of welfare, they are surely still sufficient for a slightly positive level of welfare. For what could explain why they are suddenly of no benefit at all? $?^{23}$

The judgment subjectivist is thus forced to accept either that newborn babies cannot be harmed or benefited or that there is a mysterious divergence between neonatal and normal human adult welfare. Both options seem untenable.

In a recent paper, Dorsey replies by digging in his heels and arguing that the divergence is not so mysterious after all. ${ }^{24} \mathrm{He}$ begins with the commonsense thought that when something is good for a welfare subject, it bears a positively valenced relation to that subject. He calls this the kinship relation. On his view, the kinship relation is different for different kinds of subjects. For example, the kinship relation that obtains between a dog and the things that are good for it may be a different kind of kinship relation than the kinship relation that obtains between a normal human adult and the things that are good for her. Dorsey argues that for valuers, the kinship relation is constructed by the subject's valuing attitudes; his view is that $x$ bears the kinship relation to a valuer, $S$, just in case $S$ values $x$. And, of course, he believes that a judgment-based theory of valuing is true. Thus, on Dorsey's view, the divergence between the welfare of newborn babies and that of normal human adults is explained by the fact that when the former develops the capacity to believe that something is good or bad for itself, the kinship relation that must obtain between that being and the things that are good for it is fundamentally altered.

I mention this dispute between Lin and Dorsey not to evaluate Dorsey's response to Lin. Instead, I mention it to illustrate the strength of the welfare-nihilist arguments. In reply to Lin's objection, Dorsey argues that one theory of well-being applies to normal human adults and that another applies to newborn

22 Lin, "Against Welfare Subjectivism," 358.

23 Lin, "Against Welfare Subjectivism," 360.

24 See Dorsey, "Why Should Welfare 'Fit'?" 
babies on the grounds that when a newborn baby develops the capacity to form beliefs about what is good or bad for itself, it becomes a fundamentally different kind of being. Assign to this reply whatever degree of plausibility you believe it deserves.

It is plain that a similar reply to the welfare-nihilist arguments is less plausible. It cannot be argued that the explanation as to why one theory of well-being applies to otherwise normal human adults who are welfare nihilists and another applies to normal human adults who are not welfare nihilists is because the latter have the capacity to form beliefs about what is good or bad for themselves whereas the former do not. Welfare nihilists have the capacity to form beliefs about what is good or bad for themselves. ${ }^{25}$ Having the capacity to form such beliefs is just a matter of having the capacity to come down, as it were, one way or the other, as to whether something is good or bad for themselves. Welfare nihilists like Felicity and Mallory clearly have this capacity; it is just that when they exercise it, they come to believe that nothing is good or bad for themselves. For this reason, whatever purchase Dorsey's reply has with respect to Lin's objection, it is a nonstarter as a reply to the welfare-nihilist arguments.

\section{OBJECTIONS AND REPLIES}

Each of the previous arguments relies on the general thought that some ways that a welfare nihilist's life can go can be better or worse for her than others. Judgment subjectivism is implausible because it implies otherwise. One might wonder, however, whether it is really possible to be a welfare nihilist and whether there are ways to specify the theory that do not have the implausible impli-

25 A very natural way to think of the welfare nihilist is as someone who thinks that the concept of welfare is incoherent. If we think of welfare nihilism according to this model, then we might doubt that the welfare nihilist has the capacity to form beliefs about what is good or bad for themselves. Do I, as someone who believes that the concept of a four-sided triangle is incoherent, have the capacity to form beliefs about whether something is a four-sided triangle? I am inclined to think the answer is yes, but some readers may have a different reaction. For these readers, I submit that we need not understand welfare nihilism according to this model. Instead, we can think of the welfare nihilist as someone who thinks that there are no welfare properties instantiated in this world but that there are some possible worlds where they are. Compare: I am a nihilist about unicorns. I do not think the concept of being a unicorn is incoherent; I simply deny that there are any unicorns. It can hardly be said that I have not exercised my capacity to form beliefs about unicorns simply because I do not believe that anything is a unicorn. I have indeed exercised the capacity to form beliefs about whether this or that thing is a unicorn. It is just that, in each case, I come down on the question in a particular way. For discussion of these issues as they arise in the context of morality, see Brown, "The Possibility of Morality"; and Kalf, "Are Moral Properties Impossible?" I thank an anonymous referee for raising this concern. 
cations I attribute to it. To make the discussion that follows less onerous, I will formulate each objection in terms of the case of Felicity.

\subsection{The First Objection}

You claim that Felicity believes that nothing is good for herself, but I find that difficult to imagine. After all, Felicity pursues various projects and engages in loving relationships, so she must believe that these activities are good for herself. Thus, Felicity cannot be a sincere and consistent welfare nihilist in the way that you suggest. Even if she sincerely believes that welfare nihilism is true, she clearly is not consistent because she makes ordinary, everyday judgments about what is good for herself.

I agree with the objector that one possible explanation for Felicity's behavior is that she is not a sincere and consistent welfare nihilist. That would be one coherent way to fill in the details of the case. If Felicity really did believe, for example, that being married to her husband is good for herself, that fact could explain why she got married. But this is not the only possible explanation. There is another coherent way to fill in the details of the case that does not require us to say that Felicity believes that something is good for herself.

The explanation I have in mind appeals to Felicity's intrinsic desires. An intrinsic desire is a desire for something for its own sake. Contrast intrinsic desires with mere instrumental desires. My desire for money is a mere instrumental desire; I want money because having money can get me other things that I desire. I do not desire to have green slips of paper in my pocket for its own sake. My desire for pleasure, however, is an intrinsic desire; I want pleasure for its own sake. Sometimes an intrinsic desire can also be an instrumental desire. I may want pleasure because it can get me something else that I desire, but my desire for pleasure is still an intrinsic desire as long as I also want it at least partly for its own sake. Also, intrinsic desires do not depend on beliefs about value; you can have an intrinsic desire for pleasure even if you do not believe that pleasure is good for you. ${ }^{26}$

Now suppose that Felicity pursues her various projects and engages in loving relationships because she has an intrinsic desire for pleasure and she believes that pursuing her various projects and engaging in loving relationships will result in her experiencing pleasure. Because she is a sincere and consistent welfare nihilist, Felicity does not believe that experiencing pleasure is good for herself, but she wants to experience pleasure nonetheless. When Felicity gets married, for example, we can suppose that she believes that doing so will result in her

26 Even the judgment subjectivist would accept that you can have a desire for something without believing that it is good for yourself. Otherwise, a judgment-based theory of valuing would not be much of an alternative to a desiderative theory of valuing. 
experiencing pleasure. Using this strategy, we can appeal to Felicity's intrinsic desire for pleasure (coupled with the belief that her behavior will result in her experiencing pleasure) to explain her behavior.

The objector might insist that though I have provided a possible explanation of Felicity's behavior that does not require us to say that Felicity believes that something is good for herself, I have not provided a plausible explanation of her behavior. Only an explanation that says that Felicity believes that something is good for herself can fit that bill. Or so the objector claims.

I do not know what is supposed to be so implausible about explaining a person's behavior by appealing to her intrinsic desire to experience pleasure. But in order to respond to the current objection, I do not need to argue that the explanation I offered is plausible; it only needs to cohere with the other details of the case. The fact that Felicity can coherently be described as acting on an intrinsic desire to experience pleasure (coupled with the belief that her behavior will result in her experiencing pleasure) is enough to undermine the objection. After all, Felicity is just a fictional character in a thought experiment. As long as the story is coherent, we can fill in the details as we wish. Thus, by appealing to Felicity's intrinsic desire to experience pleasure, we need not accuse Felicity of being an insincere or inconsistent welfare nihilist in order to make sense of why she pursues her various projects and engages in loving relationships. ${ }^{27}$

Furthermore, we can be relatively confident that welfare nihilists like Felicity have benefited after becoming welfare nihilists. On one interpretation, G.E. Moore was a welfare nihilist. ${ }^{28}$ Thomas Hurka has on occasion expressed skepti-

27 Some hold that $S$ 's desire that $p$ is just the state of its seeming to $S$ that $p$ is good; see Oddie, Value, Reality, and Desire. It might be thought that such a view is in tension with my strategy here; if it turns out that Felicity's intrinsic desire to experience pleasure just is her belief that experiencing pleasure is good for herself, then it could not be argued that appealing to Felicity's intrinsic desire for pleasure helps us explain various facts of her life without appealing to her beliefs about what is good for herself. I do not think this view is in tension with what I say here for two reasons. First, the view is that intrinsic desires are seemings, not that intrinsic desires are beliefs. It might seem to $S$ that $p$ even if $S$ does not believe that $p$. Second, the view is that intrinsic desires are seemings about value simpliciter, not welfare value. It might seem to $S$ that $p$ is of value simpliciter even if it does not seem to $S$ that $p$ is good for $S$. Thus, even if we think that Felicity's intrinsic desire to experience pleasure just is the state of it seeming to her that experiencing pleasure is good, that falls short of identifying Felicity's intrinsic desire to experience pleasure with a belief that experiencing pleasure is good for herself.

28 This is the view that Crisp ("Well-Being," sec. 2) and Lin ("Against Welfare Subjectivism," 359) attribute to Moore. On a competing interpretation, Moore is instead a reductionist about welfare value. On that interpretation, Moore's view is that what it is for $x$ to be good for $S$ is just for $x$ to be of value simpliciter and for $S$ to stand in the right kind of relation to 
cism about well-being. ${ }^{29}$ Bart Streumer argues that all normative judgments are false. ${ }^{30}$ Readers who find the case of Felicity difficult to imagine need only reflect on these real-world cases of welfare nihilists.

\subsection{The Second Objection}

Judgment subjectivism is the view that something is good for a person if and only if she would believe, under the proper conditions, that it is good for herself. You claimed earlier, without argument, that Felicity would not, under any plausible specification of the theory's proper-conditions clause, believe that anything is good for herself. But I can think of some plausible ways of specifying the proper-conditions clause such that the resulting theory will not have the implication that you attribute to it. And if I can supply at least one such specification, I will have limited the force of your argument in an important way: your argument, if successful, gives us reason to reject some but not all versions of judgment subjectivism.

I did indeed claim earlier that Felicity would not, under any plausible specification of the theory's proper-conditions clause, believe that anything is good for herself. I now need to make good on that claim. My strategy is to establish a presumptive case for it by showing how some candidate specifications of the proper-conditions clause fail to make the theory immune to the welfare-nihilist arguments.

\subsection{1. "If she were fully informed and fully rational ..."}

One natural and plausible-sounding strategy is to specify the proper conditions as those of full information and full rationality. The version of judgment subjectivism that would result is as follows:

$x$ is good for $S$ if and only if $S$ would believe, if she were fully informed and fully rational, that $x$ is good for $S .{ }^{31}$

$x$. This is the view that Fletcher attributes to Moore (Fletcher, "The Locative Analysis of Good for Formulated and Defended," 2-3).

29 In explaining why his perfectionism is not a theory of well-being, Hurka writes: "I do not see that 'developing human nature constitutes well-being and is therefore good' says anything over and above 'developing human nature is good,' and prefer to confine perfectionism to the second, simpler claim" (Perfectionism, 194). Hurka has also claimed that "good for" is "multiply ambiguous" and "fundamentally confused, and should be banished from moral philosophy” (“'Good' and 'Good For,” 72).

30 See Streumer, Unbelievable Errors.

31 There are some reasons to reject specifying the proper-conditions clause as conditions of full information and full rationality. There is a worry that such idealized conditions are objectionably ad hoc. For a statement of this criticism, see Enoch, "Why Idealize?" For a reply, see Sobel, "Subjectivism and Idealization." There are also concerns that no person could be 
To assess this formulation of the theory, we have to say something about what "full information" means here. Would information about what is good for Felicity be included among the information we add to her belief set when we make her fully informed?

Suppose that when we add information to Felicity's belief set to make her fully informed, we add information about what is good for her. Then the theory presupposes facts about a person's good independent of her beliefs about what is good for herself. The judgment subjectivist tells us that the fact that something is good for a person consists in her believing, under the proper conditions, that it is good for herself. But then we are told that these proper conditions include knowledge of the fact that it is good for herself. It would seem that we have an instance of a problematic kind of circularity that the judgment subjectivist should not be willing to accept.

Suppose instead that when we add information to Felicity's belief set to make her "fully" informed, we do not add information about what is good for her. In that case, there is no guarantee that Felicity will believe that something is good for herself under these conditions. Perhaps this is where the condition of being fully rational comes into play. The hope would be that it would in some sense be irrational for Felicity to be "fully" informed and still fail to believe that anything is good for herself.

Suppose that Felicity is "fully" informed and fully rational and that she does not believe that anything is good for herself. Now the version of judgment subjectivism currently under consideration would imply that Felicity is thereby irrational. But why is Felicity irrational for not believing that anything is good for herself? The judgment subjectivist must surely allow that some things are not good for a person. On any version of the theory, it must be rational for a person to believe of some arbitrarily chosen $x$ that it is not good for herself. But if a person can believe this of some arbitrarily chosen $x$ and remain rational, she should surely be able to believe it of every $x$ and remain rational.

But suppose that I am wrong about this and that it is really true that Felicity, if "fully" informed, is irrational for believing that nothing is good for herself.

fully informed and that even if a person could be fully informed, the idealized perspective may lack evaluative authority. For a statement of this criticism, see Rosati, "Persons, Perspectives, and Full Information Accounts of the Good." More generally, there is a worry that if a theory of well-being bestows evaluative authority to a person's counterfactual pro-attitudes, then that theory risks violating the resonance constraint. Such a theory might imply, for example, that my fully informed and fully rational self's desire to listen to Muzak makes listening to Muzak good for me, even if I strongly dislike listening to Muzak and do not believe that listening to it is any good for me. For a discussion of a similar alienation worry as it relates to some forms of moral rationalism, see Joyce, The Myth of Morality. 
Consider a variation of the case. This time, suppose that Felicity has no opinion about welfare (e.g., she is not a principled welfare nihilist as in the original version of the case) and that she is "fully" informed. Suppose further that by introspection she comes to hold the true belief that she does not believe that anything is good for herself. She studies the well-being literature and becomes convinced of judgment subjectivism. She then combines these two beliefs-her belief that she does not believe that anything is good for herself and her belief that judgment subjectivism is true-and deduces that nothing is good for herself. The judgment subjectivist cannot say that in this version of the case Felicity is irrational since each step of her reasoning is unassailable by the judgment subjectivist's own lights. We now have before us a different version of the case in which Felicity is both "fully" informed and fully rational, yet she still does not believe that anything is good for herself. The upshot is that specifying the proper conditions as those of "full" information and full rationality does not make the theory immune to the welfare-nihilist arguments.

We can get different versions of judgment subjectivism by tinkering with the theory's proper-conditions clause. But I have shown that the theory is undermined by the welfare-nihilist arguments if we specify those conditions to include a coherence condition, a condition of full consideration, a condition of full information, and a condition of full rationality. There may be other ways to specify the proper-conditions clause in an effort to make the theory immune to the welfare-nihilist arguments, but we at least have a presumptive case that the arguments are effective against any plausible formulation of the theory.

\section{CONCLUSION}

In this paper, I have given three related arguments against judgment subjectivism. Each argument is about how the theory implies something implausible about the welfare of welfare nihilists. The problematic feature of the theory is that it implies that something is good (bad) for a person only if she believes that it is good (bad) for herself. The welfare-nihilist arguments would be devastating against any theory with this implication. For example, Wayne Sumner's happiness theory of well-being is also subject to the welfare-nihilist arguments. On his theory, welfare consists in authentic happiness, which involves a cognitive component (in addition to an affective one). Sumner describes this cognitive component as "a judgment that, on balance and taking everything into account, your life is going well for you." ${ }^{32}$ Welfare nihilists, of course, make no such judgments, so Sumner's theory also has the implausible implications that I attribute

32 See Sumner, Welfare, Happiness, and Ethics, 145. 
to the judgment subjectivist. One upshot of this paper is that we should assess theories of well-being, at least in part, in terms of whether they deliver the intuitively correct verdicts about the welfare of welfare nihilists. ${ }^{33}$

\author{
Coe College \\ akelley@coe.edu
}

\title{
REFERENCES
}

Crisp, Roger. "Well-Being." Stanford Encyclopedia of Philosophy (Summer 2016). https://plato.stanford.edu/archives/sum2016/entries/well-being/.

Brown, Phil. "The Possibility of Morality." Philosophical Studies 163, no. 3 (April 2013): 627-36.

Dorsey, Dale. "Idealization and the Heart of Subjectivism." Noûs 51, no. 1 (March 2017): 196-217.

—. "Subjectivism without Desire." Philosophical Review 121, no. 3 (July 2012): 407-42.

—. "Why Should Welfare 'Fit'?" Philosophical Quarterly 67, no. 269 (October 2017): 685-724.

Enoch, David. "Why Idealize?” Ethics 115, no. 4 (July 2005): 759-87.

Fletcher, Guy. "The Locative Analysis of Good for Formulated and Defended." Journal of Ethics and Social Philosophy 6, no. 1 (January 2012): 1-26.

Gettier, Edmund L. “Is Justified True Belief Knowledge?” Analysis 23, no. 6 (June 1963): 121-23.

Heathwood, Chris. "Subjective Theories of Well-Being." In The Cambridge Companion to Utilitarianism, edited by Ben Eggleston and Dale E. Miller, 199-19. Cambridge: Cambridge University Press, 2014.

Hurka, Thomas. Perfectionism. Oxford: Clarendon Press, 1993. . “'Good' and 'Good For.” Mind 96, no. 381 (January 1987): 71-73.

33 I presented earlier versions of this paper at the University of Colorado Boulder on three different occasions: as a Graduate Work-in-Progress Talk, as a talk to the undergraduate philosophy club, and as a talk to the participants of the 2017 Colorado Summer Seminar in Philosophy. I am grateful to those audiences for helpful feedback. Early work on the paper was supported by funding from the Centre for Moral and Political Philosophy at the Hebrew University of Jerusalem. I am grateful for that support. For helpful comments on earlier drafts, I thank Teresa Bruno, Dale Dorsey, Nikki Fortier, Chris Heathwood, Michael Huemer, Eden Lin, Rebecca Mullen, Graham Oddie, and three anonymous referees for this journal. 
Joyce, Richard. The Myth of Morality. Cambridge: Cambridge University Press, 2001.

Kalf, Wouter F. "Are Moral Properties Impossible?" Philosophical Studies 172, no. 7 (July 2015): 1869-87.

Lin, Eden. "Against Welfare Subjectivism." Noûs 51, no. 2 (June 2017): 354-77.

Oddie, Graham. Value, Reality, and Desire. Oxford: Oxford University Press, 2005.

Railton, Peter. "Facts and Values." Philosophical Topics 14, no. 2 (Fall 1986): 5-31.

Rosati, Connie. "Internalism and the Good for a Person." Ethics 106, no. 2 (January 1996): 297-326.

- "Persons, Perspectives, and Full Information Accounts of the Good." Ethics 105, no. 2 (January 1995): 296-325.

Sarch, Alexander. "Internalism about a Person's Good: Don't Believe It." Philosophical Studies 154, no. 2 (June 2011): 161-84.

Sobel, David. “Subjectivism and Idealization.” Ethics 119, no. 2 (January 2009): $336-52$.

Streumer, Bart. Unbelievable Errors: An Error Theory about All Normative Judgments. Oxford: Oxford University Press, 2017.

Sumner, L.W. Welfare, Happiness, and Ethics. Oxford: Oxford University Press, 1996. 